\title{
Institutional Antecedents of Subsidiary External Embeddedness Coping with Regulatory Competitive Constraints
}

\author{
Santangelo, Grazia D.; Dellestrand, Henrik; Andersson, Ulf
}

Document Version

Accepted author manuscript

Published in:

Long Range Planning

DOI:

10.1016/j.Irp.2018.10.001

Publication date:

2019

\section{License \\ CC BY-NC-ND}

Citation for published version (APA):

Santangelo, G. D., Dellestrand, H., \& Andersson, U. (2019). Institutional Antecedents of Subsidiary External Embeddedness: Coping with Regulatory Competitive Constraints. Long Range Planning, 52(4), [101851]. https://doi.org/10.1016/j.Irp.2018.10.001

Link to publication in CBS Research Portal

\section{General rights}

Copyright and moral rights for the publications made accessible in the public portal are retained by the authors and/or other copyright owners and it is a condition of accessing publications that users recognise and abide by the legal requirements associated with these rights.

Take down policy

If you believe that this document breaches copyright please contact us (research.lib@cbs.dk) providing details, and we will remove access to the work immediately and investigate your claim. 


\section{Institutional Antecedents of Subsidiary External Embeddedness: Coping with Regulatory Competitive Constraints}

\section{Grazia D. Santangelo, Henrik Dellestrand, and Ulf Andersson}

Journal article (Accepted manuscript*)

\section{Please cite this article as:}

Santangelo, G. D., Dellestrand, H., \& Andersson, U. (2018). Institutional Antecedents of Subsidiary External Embeddedness: Coping with Regulatory Competitive Constraints. Long Range Planning. https://doi.org/10.1016/j.lrp.2018.10.001

DOl: 10.1016/j.lrp.2018.10.001

* This version of the article has been accepted for publication and undergone full peer review but has not been through the copyediting, typesetting, pagination and proofreading process, which may lead to differences between this version and the publisher's final version AKA Version of Record.

Uploaded to CBS Research Portal: July 2019

(C) 2019. This manuscript version is made available under the CL-BY-NC-ND 4.0 license http://creativecommons.org/licenses/by-nc-nd/4.0/ 


\title{
Institutional Antecedents of Subsidiary External Embeddedness: Coping with Regulatory Competitive Constraints
}

\author{
Grazia D. Santangelo* \\ Department of Strategy and Innovation \\ Copenhagen Business School \\ KIlevej 14a, 2000 Frederiksberg \\ Copenhagen, Denmark \\ Email: gs.si@cbs..dk \\ Henrik Dellestrand \\ Department of Business Studies \\ Uppsala University \\ Box 51375120 Uppsala, Sweden \\ Ulf Andersson \\ Mälardalen University \& BI Norwegian Business School, \\ School of Business, Society, and Engineering \\ Box 883, 72123 Västerås, Sweden \\ Email: ulf.r.andersson@mdh.se
}

\begin{abstract}
We investigate institutional antecedents to subsidiary external embeddedness and relate regulation constraining competition in local service sectors to subsidiary embeddedness with local partners in complementary sectors. Combining research on business networks with arguments derived from transaction cost economics, we argue that subsidiary external embeddedness depends on the extent of transaction costs originating from small numbers bargaining, which regulatory competitive constraints in local service sectors are a source of. Based on this logic, we suggest that low and high levels of regulatory competitive constraints are associated with greater subsidiary external embeddedness. We also suggest that this U-shaped relationship is more pronounced for subsidiaries that are centers of excellence within the multinational enterprise because these subsidiaries heavily depend on the local context as a source of their competitive advantage over their sister subsidiaries.
\end{abstract}

Keywords: External business embeddedness, institutions, factors market, foreign subsidiary, center of excellence.

\footnotetext{
${ }^{*}$ Corresponding author.
} 


\section{INTRODUCTION}

Business relationships with local suppliers and customers are a major source of competitive advantage for the subsidiary and the entire multinational network (Andersson, et al., 2002; McEvily and Marcus, 2005; Meyer, et al., 2011). External business embeddedness influences subsidiary strategy and their business operations. Embedded relationships, for instance, enable subsidiaries to access and acquire information on non-appropriable strategic assets that can translate into learning opportunities for developing innovations and improving efficiency (Andersson, et al., 2002; Dyer and Nobeoka, 2000; Dyer and Singh, 1998; Perri, et al., 2013; Rowley, et al., 2000).

Traditionally, antecedents of subsidiary external embeddedness have been identified in factors internal to the multinational enterprise (MNE) network such as subsidiary autonomy, role, entry mode, age, and size (Ambos, et al., 2011; Andersson, et al., 2005; Andersson and Forsgren, 1996; Andersson and Forsgren, 2000; Andersson, et al., 2007; Andersson, et al., 1997; Håkanson and Nobel, 2001). More recently, focus has shifted to the influence of the external environment on the extent of subsidiary external embeddedness, and on product market conditions especially (Hallin and Holmström Lind, 2011; Holm, et al., 2005; Perri, et al., 2013; Santangelo, 2012). This work suggests that business network do not occur in a vacuum, rather they are influenced by the immediate context where business actors operate. Notably, the institutional environment, such as legal and regulatory systems, defines the rule of the game (North, 1990) and influence both the strategy and business practice of foreign subsidiaries (Peng, et al., 2009; Rabbiosi and Santangelo, 2018; Santangelo and Meyer, 2011; Santangelo, et al., 2016). In particular, regulations can promote a positive environment for foreign investments or impose important constraints to foreign entry and operations (Holmes, et $a l ., 2013)$. Host governments can, for example, enact regulations in specific sectors that distort private incentives and create inefficiencies (Bourlès, et al., 2010; Levine and Renelt, 1992). Yet, the business network literature (Forsgren, et al., 2005; Håkansson, 1982) has overlooked the influence of the host institutional environment and factor market conditions on subsidiary external embeddedness. 
To advance research on subsidiary external embeddedness, we propose and test a model illustrating the influence of host country's regulatory competitive constraints in local service sectors on the external embeddedness of foreign subsidiaries operating in sectors using these services as intermediary input factors for their business activities. Building on the business network perspective and transaction cost economics (Jones and Hill, 1988; Joskow, 2002; Klein, et al., 1978; Williamson, 1975; Zajac and Olsen, 1993), we suggest that there is a U-shaped relationship between regulatory competitive constraints in local service sectors and subsidiary external embeddedness with local partners operating in complementary sectors. We explain this based on the argument that the intensity of regulation constraining competition in a sector defines the intensity of the small numbers bargaining problem and associated transaction costs (Zajac and Olsen, 1993), which foreign subsidiaries in downstream sectors must deal with. Thus, subsidiary external embeddedness with local partners is a strategic response to the extent of risks and opportunities associated with this problem and related transaction costs.

Also, we suggest that the extent to which a subsidiary is a center of excellence (CoEs) within the MNC network (Bartlett and Ghoshal, 1989; Holm and Pedersen, 2000) (i.e., has a high degree of competence as well as a high usage of that competence by sister units) positively moderates the Ushaped relationship between the host country's regulatory competitive constraints in upstream local service sectors and subsidiary external embeddedness with local partners in complementary sectors. We explain this based on the greater dependence and, hence, sensitiveness of CoE (versus non-CoE) subsidiaries to local environmental conditions (Andersson and Forsgren, 2000; Frost, et al., 2002).

To test our framework, we combine a dataset of primary data collected from 1990 to 1995 on 84 Swedish subsidiaries located in Europe and North America with secondary OECD data on regulatory competitive constraints in local service sectors for the relevant host countries and downstream sectors in the five-year period before the information on business embeddedness was collected. By focusing on the decade prior to the entry into force of General Agreement on Trade in Services (GATS), which liberalized market for services, we are able to assess the influence of anti-competitive regulation in 
services on subsidiaries embeddedness. Over time, markets for services have been liberalized. Yet, in developing countries anti-competitive regulations still characterize a number of locally provided services (see e.g., Aaker and Mbiti, 2010; Clifton, et al., 2011). This is the case, for instance, of the mobile telecom sector in the sub-Saharan region due to the strategic importance of the sector to national security and economic development (Dike, 2018). Thus, we believe that our analysis is not confined to the period and countries we analyze, and it may offer insights to countries where anticompetitive regulation in services is still high. Also, the focus on developed home and host countries enables us to control for environmental heterogeneities other than the one in focus (Cuervo-Cazurra, et al., 2016).

Our study advances research on subsidiary external embeddedness. Specifically, by drawing attention on local institutions as antecedents of subsidiary external embeddedness and the relevance of local factor market conditions for subsidiary networking strategies, we are able to integrate transaction costs arguments into research on business network and external embeddedness. In addition, we disentangle situations in which local external embeddedness is a learning strategy targeting innovation and development from situations in which local embeddedness is a learning strategy targeting efficiency improvements. From a managerial point of view, our analysis highlights the importance of considering institutions for subsidiary managers operating in host economies visà-vis building external business relationships (i.e., external embeddedness). At the same time, it can be wise for managers to be aware of their standing within the MNE given the different sensitiveness of CoE versus non-CoE units to local environmental conditions.

\section{THEORETICAL BACKGROUND}

Studies on subsidiary external embeddedness analyze differences between subsidiaries in terms of variations in resources that each subsidiary can access through its external network (Andersson, et al., 2001, 2002), which is conceived as external business relationships characterized by a high degree of mutual, long-term adaptation (Forsgren, et al., 2005). Subsidiary embeddedness, as depicted in the 
business network view, largely shares assumptions with Granovetter's (1985; 1992) view on relational embeddedness and builds on studies carried out in the 1980's revolving around formal and informal cooperation in networks (Håkansson and Johanson, 1988). The business network tradition centers on the relational dimension of embeddedness simply because relational embeddedness is strategically important (Forsgren, et al., 2005; Hite, 2003). In this perspective, the search for competitive advantage is seldom housed by a single firm and is often associated to relation-specific investments as "collaborating firms can generate relational rents through relation-specific assets, knowledge-sharing routines, complementary resource endowments, and "effective governance" (Dyer and Singh, 1998: 676). Thus, different subsidiaries are embedded in different networks, which encompass unique, idiosyncratic resources that ultimately affect subsidiary performance.

Traditionally, subsidiary embeddedness has been related to factors internal to the MNE network. Autonomous subsidiaries, those that are technological providers within the MNE network, and larger, older and acquired subsidiaries are often deeply embedded in external local business networks (Ambos, et al., 2011; Andersson, et al., 2005; Andersson and Forsgren, 2000; Andersson, et al., 2007; Andersson, et al., 1997; Håkanson and Nobel, 2001; Håkansson and Johanson, 1988). A number of studies have analyzed the subsidiary external embeddedness by focusing on environmental factors merely in terms of product market conditions (Hallin and Holmström Lind, 2011; Holm, et al., 2005; Perri, et al., 2013; Santangelo, 2012). These studies warned that local embedded relationships have a dual effect, as they simultaneously offer learning opportunities and expose the subsidiary to the risk of knowledge spillovers to the host economy, which are especially harmful for the firm's competitive advantage in the context of strong local market competition. This research points to the relevance of the external environment in influencing subsidiaries' embeddedness strategy suggesting that subsidiaries' external relationship do not occur in vacuum. Institutions such as regulation and government interventions notably define the rules of the game (North, 1990). In particular, regulations of relevant factor markets may critically influence business network relationships and the subsidiary's strategic response in terms of relationship-specific investments. 
Traditionally, most regulation has concentrated on services due to pervasive market failures and the influence of domestic interest groups to limit foreign competitive pressures in these sectors (Mustilli and Pelkmans, 2012; Nicoletti, 2001). The focus of anti-competitive regulation on services parallels the escalated importance of service sectors as suppliers of factor inputs (François and Hoekman, 2010). Historically, manufacturing firms have been shown to depend on key service factors, such as professional activities, energy, transport, retailing, telecommunication, and financial services to effectively do business (Melvin, 1989). Because import penetration is much more limited in services than in manufacturing sectors, business services' consumers have little alternative than to purchase these products on the domestic market (Conway and Nicoletti, 2006). Also, the provision of some services requires access to local infrastructures, and global competition can be prevented when such access is limited to local monopolist or oligopolistic firms by anti-competitive regulations. As a result, the level of regulation constraining competition in locally-provided services has important implications for the economic growth of a country (Barone and Cingano, 2011) and the strategy and performance of firms in downstream sectors (Conway and Nicoletti, 2006; Kongsrud and Wanner, 2005). Regulation that creates barriers to entrepreneurship and restricts competition in domestic markets, in which technology and demand conditions would make competition viable, limits supply and raises transaction costs originating from small numbers bargaining for firms in downstream sectors (Jones and Hill, 1988; Joskow, 2002; Klein, et al., 1978; Williamson, 1975; Zajac and Olsen, 1993). Thus, firms in downstream markets tend to strategize on their local relationships to acquire critical resources and information to face the consequences of upstream markets. In other words, competition and regulations related to competition influence how firms act on a market, and thus how they relate to each other, that is, it influences firms' external embeddedness.

By distorting competition dynamics in local sectors supplying inputs to a wide range of downstream markets, regulatory competitive constraints in services affect the incentives of the subsidiaries operating in these downstream markets to embed locally in order to access and acquire critical resources and information. 
An increase in the level of regulatory competitive constraints raises barriers to entry and/or distorts market structure relative to a competitive outcome, reducing the number of firms in the regulated sectors. In this situation, firms using the inputs produced in the regulated sectors face greater transaction costs originating from small numbers bargaining (Williamson, 1975). Small numbers bargaining situations are characterized by ex-post opportunism or hold-up problems that lead to exante efforts to negotiate terms and conditions in contracts which offer protection but may at the same time influence the relationship (Joskow, 2002). These efforts are also costly, time-consuming to agree upon, and are never totally successful when contracts are incomplete. Instead, absent or limited regulatory competitive constraints in specific sectors enhance opportunities for the relevant transactions and attenuates small numbers trading conditions and associated opportunism problems for firms in downstream sectors (Jones and Hill, 1988). In these situations, firms in downstream sectors benefit most because they have multiple upstream relationships that can be played against each other to force suppliers to compete by being more innovative (Porter, 1990). Therefore, the intensity of the small numbers problem substantively defines the intensity of the associated transaction costs (Zajac and Olsen, 1993).

\section{DEVELOPMENT OF HYPOTHESES}

\section{The influence of regulatory constraints in local service sectors}

Externally embedded relationships in complementary sectors are a strategic response by foreign subsidiaries to different learning opportunities associated with low or high regulatory competitive constraints in upstream local service sectors. Put differently, industry competition in factor markets is conceived as influencing the extent to which firms embed in local network relationships.

In situations characterized by low levels of regulatory competitive constraints in the local service sectors, the number of actors in the regulated sectors will be higher and the associated transaction costs for firms supplying from these sectors lower than in situations characterized by intermediate and high levels of regulatory competitive constraints. The possibility to transact with a potentially 
large number of service suppliers reduces the risks that these suppliers will behave opportunistically and pressures them to innovate to outperform competitors and increase their market share (Porter, 1990). Thus, firms in downstream sectors can benefit from these potential multiple relationships with services suppliers by playing these providers against each other and forcing them to engage in a competitive race for innovation (Jones and Hill, 1988; Porter, 1990). However, to fully exploit the abundance of innovative intermediary supplies and knowledge spillovers from competitive service sectors foreign subsidiaries will embed with local partners operating in sectors that are complementary to services. The market-specific knowledge of these partners facilitates subsidiaries' learning for development and innovation purposes by highlighting opportunities for recombining a large variety of high-quality service inputs (Andersson, et al., 2002; Dyer and Singh, 1998; Perri, et $a l ., 2013)$. The evocations and feedback on unique resource combinations subsidiaries can gather from embedded local relationships provide substantial learning opportunities to recombine the large variety of high-quality service inputs firms. The corollary to this is that foreign subsidiaries and their local partners enjoy great learning opportunities that are munificent for dealing with competition.

In the opposite situation of high regulatory competitive constraints, in which the competitive dynamics in the local service sectors becomes stifled, and opportunistic behavior due to small numbers bargaining prevails, the learning opportunities are again elevated (compared to moderate levels of regulatory competitive constraints), but for reasons of efficiency rather than learning (Andersson, et al., 2002; Dyer and Nobeoka, 2000). For high levels of regulation constraining competition in local service sectors, the number of potential trading partners is significantly lower for foreign subsidiaries in downstream sectors and the risk that the few service providers will act opportunistically higher. In these situations, the relevant issue for foreign subsidiaries becomes embedding in relationships in sectors complementary to services to limit transaction costs and utilize service inputs as efficiently as possible (Joskow, 2002).. In particular, when local service providers hold oligopolistic positions and, thus, enjoy greater market power, foreign subsidiaries in downstream sectors are forced to transact with them and need to safeguard against their opportunistic behaviors 
(Williamson, 1985). To this end, foreign subsidiaries in downstream sectors will be willing to establish trusting relationships with local partners to gather specific information and learn how to improve their efficiency in business and production when using locally provided services (Dyer and Nobeoka, 2000; McEvily, et al., 2003; Rowley, et al., 2000). Higher degrees of external embeddedness with local partners enables foreign subsidiaries to gather information and safeguard against opportunistic behavior in the regulated service sectors.

In intermediate levels of regulatory competitive constraints in local service sectors, the extent to which a subsidiary embeds in its local relationships is lower. In relation to lower levels of regulatory constraints, enacting regulations reduces the number of firms and competition in the regulated sectors and limits foreign subsidiaries' learning opportunities when embedded with their local partners. In relation to high levels of regulatory constraints, the number of service suppliers is higher and competition in these sectors is less limited. Thus, foreign subsidiaries have less need to embed to gather information and learn how to improve their efficiency.

The discussion above suggests a U-shaped relationship between the level of regulation constraining competition in local service sectors in a host country, and the extent of subsidiary embeddedness with local partners. The anti-competitive regulation and further liberalization in financial and telecommunication services in China is illustrative. Before the 2002 entry of China in WTO, anti-competitive regulations constrained the development of, among others, e-commerce in downstream sectors. Dell, which is the pioneer of online direct sales, initially encountered difficulties in selling its products online and had to resort to local partners in sectors complementary to financial and telecommunication services, which had a better understanding of the Chinese market, to efficiently use the locally provided services (Wong, et al., 2004). After China's entry in WTO, the liberalization in financial and telecommunication services facilitated innovation in these sectors and Dell established strategic cooperations with local partners in the fields of big data and cloud to fully exploit opportunities for learning and development, which stem from the use of locally provided innovative services solutions (Dell, 2015). Thus, we suggest: 


\begin{abstract}
H1: There is a curvilinear (U-shaped) relationship between the extent of regulatory competitive constraints in relevant local service sectors and subsidiary business embeddedness with local partners in complementary sectors.
\end{abstract}

\title{
The moderating effect of a CoE subsidiary role
}

MNE subsidiaries differ in terms of the capabilities that each subsidiary develops (Bartlett and Ghoshal, 1989; Gupta and Govindarajan, 1991). More capable subsidiaries, which are often labeled CoEs, are organizational units that embody a set of capabilities that have been explicitly recognized by the MNE as an important source of value creation, with the intention that these capabilities be leveraged by and/or disseminated to other parts of the firm (Bartlett and Ghoshal, 1989; Frost, et al., 2002; Holm and Pedersen, 2000).

CoE subsidiaries can be strongly embedded in the local environment, which then is a major source of learning opportunities, critical resources, and their competitive advantage over other subsidiaries within the MNE (Andersson and Forsgren, 2000; Frost, et al., 2002). Resources that feed into subsidiary competences that are critical for the subsidiary's CoE status are derived from the external environment (Andersson, et al., 2014). As a result, CoEs are predicted to be more sensitive to local environmental conditions than non-CoE subsidiaries. Thus, the extent to which a subsidiary is recognized as a $\mathrm{CoE}$ within the corporate network can be conceived of as influencing the degree of subsidiary external embeddedness with local partners in complementary sectors as a response to different levels of regulatory constraints in local service sectors.

For low levels of regulatory competitive constraints, CoE subsidiaries are more externally embedded with local partners than non-CoE subsidiaries. The former strongly depend on the local context to capture local knowledge, which is then provided to the MNE network (Figueiredo, 2011; Frost, et al., 2002). For high levels of regulation constraining competition in local service sectors, the risks of opportunistic behavior become substantial, so CoE subsidiaries embed more in their local network to gather information and learn how to improve efficiency than non-CoE subsidiaries do. 
The former have more at stake because they aim to maintain their role, responsibilities, and bargaining power within the MNE network.

For intermediate levels of regulatory competitive constraints in the local service sectors $\mathrm{CoE}$ subsidiaries embed less in their local relationships in complementary sectors than non-CoE subsidiaries. CoE subsidiaries are more ready to sacrifice their investments in trusting relationships with external local partners when the learning opportunities associated with a large or small number of services suppliers are available, that is, when the gains from local embeddedness are lower. Limited learning opportunities can drastically reduce knowledge flows from the CoE subsidiary to other subsidiaries within the MNE network, and thereby its possibilities to fulfill its responsibilities within the MNE, if it does not quickly shift its attention to other sources of knowledge. As knowledge is power, changes in the direction of knowledge flows determine shifts in power (Mudambi and Navarra, 2004). When opportunities to learn for innovation and development or for efficiency improvements through local embedded relationships are lower, $\mathrm{CoE}$ subsidiaries reduce their commitment to the local network and consider alternative knowledge-creation opportunities to maintain their bargaining power within the MNE network. Thus, we suggest the following:

H2: The extent to which subsidiaries play a CoE role within the MNE moderates the U-shaped relationship between the extent of regulatory competitive constraints in local service-supplying sectors and subsidiary business embeddedness with local partners in complementary sectors, such that the U-shaped curve is more pronounced for CoE subsidiaries.

\section{METHOD}

\section{Data and sample}

For this study, 13 MNEs from Sweden's OMX Large Cap list agreed to participate. The sample covers a variety of industries, such as pulp and paper, telecommunications, petrochemicals, hard materials, power systems, and equipment and machinery manufacturing. 
We initially approached the managing directors of 20 international divisions, rather than the firms' corporate headquarters. This was because divisional headquarters have direct management relationships with subsidiaries, and knowledge about subsidiary activities is primarily an intradivisional issue, as the divisionalisation of the MNE separates the various businesses from each other (Egelhoff, 1988; Stopford and Wells, 1972). All of the business areas were highly international, with 75 percent having more than half of their employees located outside the home country. We gathered data from 97 subsidiaries active in these divisions, located in Europe and North America.

An average of five subsidiaries was studied within each division, although the number varied between two and nine. With the intention of increasing the possibility of drawing general conclusions, each divisional headquarters was asked to assist in selecting subsidiaries that were representative of the business area's activities. On average, the subsidiaries in the sample accounted for more than 50 percent of their respective business areas' combined operations, measured in terms of the number of employees. In 25 percent of the business areas, the investigated subsidiaries accounted for more than 80 percent of the business area's total operations and accounted for between 10 percent and 60 percent in the remaining business areas. The number of employees in the subsidiaries varied between 50 and more than 5,000. All subsidiaries were responsible for their own production and sales. Product and production-process development were important activities in all the studied subsidiaries.

We gathered the data through face-to-face interviews based on a standardized questionnaire. The questionnaire was carefully developed by incorporating feedback from several academics that identified various questions in the initial questionnaire as vague, ambiguous, or possible sources of bias. The questionnaire was pilot tested on an experienced manager in an MNE not approached in the actual study. Our instrument was subsequently modified in accordance with feedback received from scholars and the manager. At each subsidiary, three managers (the subsidiary CEO, sales manager, and purchasing manager) were interviewed, resulting in a total of 291 interviews at the subsidiary level. These were complemented by 20 interviews at the global business area level. The latter 
interviews involved one person from each top management team (in most cases, the CEO of the business area).

We focus on externally embedded relationships with partners operating in the manufacturing sector for three main reasons. First, complementarity between service and manufacturing inputs results in intense knowledge spillovers, information flows, and mutual dependence (Baptista and Swann, 1998; Chi, 1994; Scherer, 1984; Teece, 1986). Second, feedback from local manufacturing partners is critical for the use of locally provided service inputs for the final product (Von Hippel, 1998), particularly for foreign affiliates which lack market-specific knowledge (Johanson and Vahlne, 2009). Third, manufacturing sectors are typically lightly regulated or unregulated, and open to international competition (Conway, et al., 2006). Thus, subsidiaries can effectively evaluate and freely select preferential business partners among manufacturing suppliers and customers outside regulatory constraints. Figure 1 illustrates our research setting.

\section{INSERT FIGURE 1 HERE}

Due to missing values, the analysis covers only 84 subsidiaries active in the 20 international divisions. For each host country, data on regulatory competitive constraints in service sectors supplying the sector where the subsidiary operates was gathered from the OECD Product Market Regulation database. Data collection took place from 1990 to 1995 . We combine these primary data with OECD secondary data on regulation impact concerning the five-year period before the information on business embeddedness was collected based on the idea that it takes time for regulations to influence firms' networking behavior. This way of proceeding enables us to assess the influence of regulatory competitive constraints in local service sectors on subsidiary external embeddedness prior the entry into force of GATS in 1995. Anti-competitive regulation in services is still in place in many developing countries and, thus, is an issue foreign firms in downstream sectors face when operating in these countries. However, replicating our analysis in a more recent period in 
developing countries would require to discount additional institutional complexity and this task may be difficult to be properly operationalized.

\section{Dependent and independent variables}

Subsidiary external business embeddedness is operationalized by building on observations that a firm's key components of embeddedness (Granovetter, 1985; Granovetter, 1992) concerns interaction and adaptation to external business relationships (Ford, 1990; Forsgren, 1989; Håkansson, 1982). In relation to the subsidiary's general business activity, external business embeddedness reflects the extent to which the subsidiary's relationships with external suppliers and customers depart from arm's-length relationships. This definition highlights two aspects that an effective measure of external business embeddedness should encompass: the degree of adaptation of the subsidiary's business behavior to external business partners; and the breadth of the subsidiary's contacts with such partners.

Consequently, each subsidiary's sales and purchasing managers were asked to estimate the extent to which the subsidiary had adapted its way of doing business because of its relationships with the most important external manufacturing customers and suppliers (five-point Likert-type scale ranging from $1=$ not at all to $5=$ very much). To obtain a general measure of business adaptation, the scores for the adaptation of business conduct in each external relationship were added and then divided by the number of external relationships. In addition, we asked the sales and purchasing managers to assess the number of different functional areas (such as chief executives, administration, purchasing, sales, production technical staff, and R\&D) that had direct contact with the most important manufacturing customers and suppliers. The higher the number of functional areas involved, the greater the investment in the relationship and the higher the possibility of absorbing useful knowledge about general business conditions. We divided the number of different functional areas by the number of external relationships to obtain a general measure of the breadth of business contacts. Respondents were asked to identify their three most important manufacturing customers and three most important manufacturing suppliers. ${ }^{\text {ii }}$ External business embeddedness is a single composite measure based on 
the loadings from a principal component factor analysis of the two resulting items ${ }^{\mathrm{iii}}$ (construct reliability $[\mathrm{CR}]=0.80){ }^{\mathrm{iv}}$

To measure regulatory competitive constraints in local service sectors, we relied on the OECD indicator of regulation impact. In each host country, and for each sector in which the focal subsidiary operates, the indicator was calculated as:

$$
\mathrm{RI}_{k t}=\sum_{j} \mathrm{R}_{j t} \mathrm{~W}_{j k}
$$

where $R I_{j t}$ is an indicator of regulatory competitive constraints in service sector $j$ at time $t$, and the weight $w_{j k}$ is the total factor requirement of sector $k$ for intermediate factors of the $j$ sector. The total input coefficient $w_{j k}$ measures the importance of the regulated $j$ sector as a supplier of intermediate inputs for the $k$ sector. These coefficients are derived from (harmonized) input-output tables, which provide a snapshot view of the purchases and sales of intermediate factors between different sectors (OECD, 2001). In other words, the measure relates the relevant local service sectors $j$ to the sector $k$ in which each focal subsidiary operates. The locally provided services include energy, transport, communication, retail distribution, professional services, and finance. Regulatory constraints in these sectors relate to regulatory measures that "curb entry and/or distort market structure relative to a competitive outcome" (Conway and Nicoletti, 2006: 7) and cover barriers to entry, state involvement in business operations, and market structure. To allow for time-lagged effects on subsidiary business embeddedness, we averaged the measure over the five-year period before the information on business embeddedness was collected.

We define CoE-subsidiaries as those subsidiaries that possess superior capabilities recognized as a source of value creation within the MNE, i.e., that have a high degree of competences and the level of usage of those competences is also high (Bartlett and Ghoshal, 1989; Forsgren and Johanson, 1992; Holm and Pedersen, 2000). To measure the role of the subsidiary as a CoE, we relied on the divisional headquarters management's assessment of the subsidiary's importance for product and production development for sister subsidiaries. More specifically, we asked respondents to indicate the extent to which the subsidiary was important for its sister units in: 1) product- and 2) production-development 
activities (five-point Likert-type scale, ranging from $1=$ very small to $5=$ very high). $C o E$ is a single composite measure based on the loadings from a principal component factor analysis of the two items $(\mathrm{CR}=0.86){ }^{\mathrm{v}}$

\section{Control variables}

After the data collection, research has obviously advanced the knowledge in the area we are addressing. A number of external and internal factors to the MNE network have been found to influence subsidiary external business embeddedness, which we included in our model. In relation to external factors, research has highlighted the impact of product-market competition on subsidiary embeddedness (Holm, et al., 2005; Perri, et al., 2013; Santangelo, 2012). In particular, we focused on the extent to which subsidiaries' buying and selling activities are influenced by competitors. To do so, we relied on a measure developed by Perri, et al. (2013) that is reflected in the data that we have available. The subsidiary purchasing and sales managers were asked to indicate the extent to which competitors influenced the most important customer or supplier relationships identified for the dependent variable (five-point Likert scale, ranging from $1=$ not at all to $5=$ very much). Purchasing managers were instructed to only rate the influence on supplier relationships, while sales managers were asked to only rate the influence on customer relationships. The scores for each of the subsidiary's relationships were added and then divided by the number of relationships. This process resulted in a perceptual measure of the average influence exerted by competitors in the subsidiary's local environment on the most important vertical relationships maintained by the subsidiary (productmarket competition).

We classified factors internal to the MNE network that might influence subsidiary business embeddedness as those related to the headquarters-subsidiary relationship or as subsidiary-specific characteristics. Coordination and control mechanisms influence subsidiary behavior (Martinez and Jarillo, 1989). In particular, the degree of formalization of headquarters-subsidiary relationships is related to subsidiaries' embeddedness in local business relationships (Gates and Egelhoff, 1986; 
Snell, 1992). To operationalize the degree of formalization of headquarters-subsidiary relationships, we asked each subsidiary's CEO to indicate the extent to which the subsidiary relied on written manuals from headquarters concerning: 1) marketing and 2) the company philosophy (five-point Likert-type scale ranging from $1=$ not at all to $5=$ very much). Degree of formalization is a single composite measure based on the loadings from a principal component factor analysis of the two items $(\mathrm{CR}=0.86) .{ }^{\mathrm{vi}}$ As a subsidiary's perception of headquarters' control relates to the degree of embeddedness with local business partners (Hedlund, 1980), we accounted for this aspect of headquarters-subsidiary relationships in the model. As a proxy for subsidiary-perceived control by headquarters, we asked respondents to state the extent to which the subsidiary could independently make decisions regarding 1) investments in production capacity, 2) investments in $R \& D$, and 3) acquisitions within its own country. Perceived control by headquarters is a single composite measure based on the loadings from a principal component factor analysis of the three items $(\mathrm{CR}=0.84) .{ }^{\mathrm{vii}}$ We also controlled for headquarters' direct control of subsidiary operations, which is usually exercised through the use of expatriate managers (Snell, 1992). Expatriates is a binary variable equal to 1 if the subsidiary hosts expatriates managers and equal to 0 otherwise.

In terms of subsidiary-specific characteristics, we controlled for entry mode, age, size, and industry context. Acquired subsidiaries have time to establish themselves in local knowledge networks and are expected to be more deeply embedded than greenfield subsidiaries (Erramilli and Rao, 1990). However, the successful establishment of local embedded relationships may be more uncertain when acquisitions are initiated by headquarters, which lacks as much reliable market network knowledge (Andersson, et al., 1997), than when they are initiated by local subsidiaries. We included a binary variable accounting for acquisition as the entry mode. The age of the subsidiary also influences local embeddedness. The successful development of a local embeddedness strategy depends on long-term relationships that are largely based on trust and mutual commitment (Andersson and Forsgren, 2000; Håkansson, 1982). As a result, older subsidiaries have an advantage over younger ones (Rabbiosi and Santangelo, 2012). To account for this factor, we operationalized 
subsidiary age as the length of time that passed from the year the subsidiary was established to the year the survey was conducted.

In addition, the successful development of local embedded relationships requires extensive resources, which larger subsidiaries are more likely to possess (Andersson, et al., 2005). Larger subsidiaries are also more likely to perform additional functions that create more opportunities for interfaces with local counterparts than those that smaller subsidiaries encounter (Andersson, et al., 2005). To control for subsidiary size effects, we included a variable measuring the percentage of subsidiary sales relative to the MNE's total sales. We also considered industry effects, as firms' behavior vary significantly across the range of industries. In particular, high-tech firms appear to behave differently from other firms (OECD, 1992), indicating that industry context may influence firms' relational behavior (Hagedoorn, 2006). Thus, we included a binary variable for high-tech industries, as classified in the OECD-Eurostat technology-intensive sectoral classification (2006).

\section{Method bias}

Although we combined primary and secondary data in our analysis, we used primary subjective data for the dependent, and most of the independent, variables. The use of perceptional measures in questionnaire-based studies typically raises concerns about common method variance (Campbell and Fiske, 1959; Campbell, 1982; Cronbach and Meehl, 1955). To minimize the potential impact of common method bias, we took a number of precautions. First, respondents were provided with assurances of confidentiality to ensure unbiased responses (Podsakoff and Organ, 1986). Second, we used multiple respondents, thereby reducing the risk of a single source of variance (Podsakoff and Organ, 1986). Third, the questions relating to the dependent and independent variables were located in different parts of the questionnaire. Fourth, we extracted complex constructs based on a number of items, and our models include quadratic effects and interaction effects. The third and fourth measures taken reduce the risk of respondents forming implicit theories and creating illusory correlations during data collection (Podsakoff and Organ, 1986; Smither, et al., 1989). Together with combining primary 
and secondary data, these steps effectively limit the likelihood of concerns related to common-method bias (Siemsen, et al., 2010). Furthermore, they also resonate with recent research on how to limit potential common method variance concerns (e.g., Podsakoff, et al., 2003).

To test that our results were not affected by common method bias, which would inhibit the validity of our findings, we performed a Harman's single-factor test on the items included in our model (Podsakoff and Organ, 1986). If common method bias existed in the data, a single factor would emerge from a factor analysis of all measurement items or one general factor would account for most of the variance. The factor analysis revealed four factors with eigenvalues greater than 1 , with the first explaining 20.64 percent of the total variance. This result indicates that there was no single background factor and supports the validity of our data.

\section{RESULTS}

Table 1 presents the correlation matrix and descriptive statistics. An inspection of the correlation matrix does not signal any multicollinearity concerns. The highest mean VIF is 6.10 . We also checked the condition numbers against the cut-off value of 30 (Belsley, et al., 1980). The highest condition number value we obtained in the various models was 13.98 , which suggests global stability of the regression coefficients. Multicollinearity is not a problem, as indicated by the bivariate correlation and the condition number value. Although multicollinearity does not appear to be an issue, we followed Golden and Veiga (2005) in calculating the correlation between the quadratic term and CoE $(r=0.08$, n.s. $)$ to ensure that the power of the moderated regression was not undermined (Cortina, 1993). In addition, variables that enter into interaction terms were mean-centered in advance to reduce multicollinearity, as suggested by Aiken and West (1991).

INSERT TABLE I HERE 
We ran stepwise OLS regressions, in which we first entered the controls (Model 1), and then the linear term (Model 2), followed by the quadratic term (Model 3), the linear interaction (Model 4), and the quadratic interaction (Model 5), as shown in Table 2. ${ }^{\text {viii }}$ Model 5 is the fully specified model. To control for possible headquarters-subsidiary dyad non-independence, we used Stata's cluster option to rule out firm-level effects and obtain a robust variance estimate that adjusts for within-cluster correlation (Williams, 2000).

\section{INSERT TABLE II HERE}

A curvilinear relationship exists if the addition of the quadratic term results in significant incremental variance after the linear effect has been taken into account (Cohen, et al., 2003). Hypothesis 1 predicts that the relationship between the extent of regulatory competitive constraints in local service sectors and subsidiary external business embeddedness will be U-shaped. As shown in Table 2 (Models 3 to 5), the quadratic term coefficient is positive and significant, and the increase in model fit after first inserting the term is also significant $\left(\Delta R^{2}=0.016, \mathrm{p}<0.05\right)$. Figure 1 , which graphs the U-shaped relationship, suggests that the curve initially slopes downward, turns upward, and then becomes positive at more extensive levels of regulatory competitive constraints in locallyprovided service-supplying sectors. Thus, hypothesis 1 is supported.

\section{INSERT FIGURE 2 HERE}

To test for a moderating effect on the curvilinear relationship between regulatory competitive constraints in local service sectors and subsidiary external embeddedness with local manufacturing partners, we entered the quadratic interaction last into the regression analysis after the direct effect and linear interaction terms. We found evidence of moderation when the quadratic interaction was significant in the hypothesized direction, and the model fit improved (Golden and Veiga, 2005; Xie and Johns, 1995). 
Hypothesis 2 posits that the extent to which a subsidiary plays a CoE role within the MNE network moderates the U-shaped relationship between regulatory competitive constraints in local service sectors and subsidiary external business embeddedness. In our fully specified model (Model 5), the quadratic interaction term is positive and significant at the 5-percent level, and the inclusion of this term improves the model fit $\left(\Delta R^{2}=0.021\right.$, significant at $\left.\mathrm{p}<0.05\right)$. Thus, hypothesis 2 is supported. To better interpret this interaction term, we graphed the quadratic-by-linear effect using the procedure outlined in Cohen, et al. (2003) and Aiken and West (1991). Figure 2 shows that the U-shaped relationship between the extent of regulatory competitive constraints in local service sectors and subsidiary external embeddedness is more pronounced for subsidiaries that are largely CoEs within the MNE network. For these subsidiaries, the degree of external business embeddedness associated with low and high regulatory competitive constraints in local service sectors is higher than for nonCoE subsidiaries. For these subsidiaries, the U-curve relationship flips shape becoming an inverted U-curve relationship most likely because embeddedness is about mutual dependence. Thus, local partners increasingly channel resources to establish embedded relationships with non-CoE subsidiaries as regulatory competitive constraints in local service sectors raise from low to intermediated level, and CoE subsidiaries' interest in local embedded relationships diminishes. They increasingly divert resources from establishing embedded relationships with non-CoE subsidiaries for intermediate and higher levels of regulatory competitive constraints in local service sectors because the associated increase in CoE subsidiaries' interest in establishing embedded relationships offers greater opportunities to access superior knowledge and technology.

\section{INSERT FIGURE 3 HERE}

A number of controls returned significant. In particular, product-market competition was positively associated with subsidiary external business embeddedness, which is in line with recent studies on embeddedness. ${ }^{\text {ix }}$ The extent of subsidiary external business embeddedness is lower for acquired subsidiaries and higher for large and high-tech subsidiaries. 


\section{Robustness checks}

Given the small size of our sample, concerns may arise regarding the possibility that outliers may drive the curvilinear relation (Meyer, 2009). To rule out this concern, we re-ran Model 3 by estimating a robust regression, which dropped the most influential data points and assigned lower weights to the cases with large residuals ( $\mathrm{Li}, 1985)$. In addition, we re-estimated Model 3 by eliminating potential outliers. In both cases, the curvilinear regression was confirmed.

\section{DISCUSSION}

Although markets for services have been liberalized over time, in developing countries locally provided services are still heavily regulated by anti-competitive regulations, which pose substantial challenges to firms in downstream sectors and foreign investors, especially. For example, regulationconstrained competition in services in China before 2002, and in telecommunications in the subSaharan region still today has had a drastic impact on firms' business relationships in downstream sectors. In both contexts, firms using inputs from local service providers have to look for efficient ways to rely on their local business relations to effectively use these inputs. Instead, in contexts where service sectors are liberalized, firms in downstream sectors can rely on their local business relations to exploit opportunities for learning and product development stemming from the use of locally supplied innovative service solutions.

We analyze the influence of the host institutional environment, in the form of regulatory competitive constraints in local service sectors, on the strategic management of external business network relationships with local partners. We argue and empirically show that a subsidiary's external business embeddedness in complementary sectors varies with the degree of regulatory competitive constraints in local service sectors. Also, we offer theoretical arguments and empirical evidence that the role of the subsidiary in the internal business network (i.e., CoE versus non-CoE) moderates this relationship. In particular, CoE subsidiaries are more sensitive to regulatory competitive constraints 
in the host country, as the local environment is a major source for their possibilities to fulfill their CoE responsibilities.

The study offers three contributions to the stream of research on business networks and subsidiary external embeddedness in particular. A first contribution focuses on the host institutional environment in relation to subsidiary external business embeddedness. Recent studies on subsidiary embeddedness have investigated the external environment as an antecedent of subsidiaries' embeddedness (Hallin and Holmström Lind, 2011; Perri, et al., 2013; Santangelo, 2012), merely in terms of product market competition. Our study builds on the idea that network relationships do not occur in a vacuum, and advances this work by focusing on institutions, which notably define the rule of the game. In particular, we suggest that foreign subsidiaries also adapt their embeddedness to the specific host country's regulatory framework. This contributes to an enhanced understanding of antecedent to external business embeddedness. The business network literature is relatively silent on institutional drivers of subsidiary embeddedness in external relationships (Forsgren, et al., 2005). Thus, our findings offer an explanation related to host country conditions, above and beyond munificent and competitive environments, that extend earlier network literature. Also, the business network perspective has been relatively silent on how transaction cost considerations may influence the formation of trustful long-term adaptive relationships. By accounting for the institutional drivers of external embeddedness, we are then able to integrate transaction cost arguments into research about business networks and external embeddedness. In particular, we propose that regulatory competitive constraints raise small numbers bargaining issues, which create conditions for opportunistic behavior that subsidiary embeddedness may strategically address. Thus, the integration of transaction cost arguments in the business network traditions enables to broaden the scope of how business relationships can be conceived.

A second contribution concerns the market subject to the host country's regulation. In particular, our analysis enables us to account for regulation in a relevant factor market. Although the conceptual starting point of the external network view of the firm (Dyer and Singh, 1998; Uzzi, 1997) relates to 
research in the resource-based view tradition, which has long recognized the relevance of imperfect and incomplete factor markets for firms' sustained competitive advantages (Barney, 1986; Dierickx and Cool, 1989; Penrose, 1959; Peteraf, 1993; Rumelt, 1984; Wernerfelt, 1984), the business network view of the MNE has mostly neglected factor market conditions as an antecedent to subsidiary strategic network behavior. We advance this research by extending our knowledge on the factors market conditions influencing subsidiary external embeddedness.

Finally, our analysis also contributes to research on subsidiary external embeddedness by disentangling scenarios in which embeddedness is a strategy aiming at learning for innovation, development, and improving efficiency. Extant research has pointed out the dual strategic goal of embeddedness (Andersson, et al., 2002; Dyer and Nobeoka, 2000; Dyer and Singh, 1998; Perri, et al., 2013; Rowley, et al., 2000), but left largely unexplored the conditions under which each of these strategies is more likely. Our study sheds light on these scenarios by relating embeddedness for innovation- and efficiency-driven learning to specific local regulatory conditions. Also, by bringing the role of the subsidiary to the fore (i.e., the subsidiary considered as a CoE or not) we elucidate the interplay between the internal MNE business network and how host country regulations influence the degree of external embeddedness.

\section{Managerial implications}

The study has managerial implications for both subsidiaries and headquarters.

Our results warn subsidiary managers that different levels of host regulatory competitive constraints in critical factor markets requires different strategic responses in terms of embeddedness in the external business environment. In particular, external embeddedness may help subsidiaries to take up opportunities related to learning for innovation and development when regulatory constraints are absent or limited. Instead, it may help subsidiaries to deal with learning for efficiency improvements when regulatory constraints are high. Understanding these different strategic responses subsidiaries 
may offer in different host country institutional conditions may help managers design better strategies for sustaining subsidiaries' competitive advantages.

The implications related to headquarters speak to the dissimilar sensitiveness that different multinational units display in terms of external embeddedness in response to varying host country institutional conditions. In particular, headquarters managers need to be aware that the sensitiveness of subsidiaries varies across the MNE depending on the roles they play within the internal network. CoE subsidiaries are more sensitive to environmental conditions as the local context is a major source of knowledge that also is connected to subsidiaries capability development in order to fulfil their responsibilities within the MNE that also feeds into subsidiaries competitive advantage over sister units within the MNE.

\section{Limitations and further research}

The study suffers from a number of shortcomings, which may guide future research on this topic. In particular, our dataset concerns subsidiaries originating from a single home country, but targeting multiple host countries. Thus, we were unable to capture home-country effects. The consideration of multiple host and home countries would require a complex primary data-collection process, which future research may wish to undertake. Second, we consider only developed countries as home and host locations. It would be interesting to test our framework in situations in which home and host countries display different levels of development using more updated data. Such a research design would allow emerging or transition economies, in which institutions notably play an even more critical role (Santangelo and Meyer, 2011), to be taken into account. These issues notwithstanding, we are confident that this study contributes to our knowledge of subsidiary external embeddedness, the role of institutions, and the CoE's associated effect on embeddedness. 


\section{NOTES}

${ }^{\mathrm{i}}$ To rule out that our results may be driven by the 13 subsidiaries whose business embeddedness information was collected in 1995, we re-run our model by first controlling for these subsidiaries and then dropping them. In both cases, our findings are supported.

ii See Andersson, et al. (2002) for a discussion on the motivations for selecting the three most important customers and suppliers.

${ }^{\text {iii }}$ Factor loadings: Number of different functional areas directly involved in the relationship with the business partner $=$ 0.815 ; adaptation of business conduct $=0.815$; eigenvalue $=1.328$; variance explained $=66.38 \%$.

iv We choose to rely on CR as an alternative to Cronbach's alpha, as the latter highly depends on the number of items (Hair et al., 2006). We followed Hair et al. (2006) and calculated CR by taking the square of the added loadings and the sum of the error variance terms for the construct.

${ }^{\vee}$ Factor loadings: Product development activities $=0.865$; production development activities $=0.865 ;$ eigenvalue $=1.498$; variance explained $=74.88 \%$.

${ }^{\text {vi }}$ Factor loadings: Marketing $=0.873$; company philosophy $=0.873$; eigenvalue $=1.526$; variance explained $=76.28 \%$.

${ }^{\text {vii }}$ Factor loadings: Investments in production capacity $=0.889$; investments in $R \& D=0.686$; acquisitions within its own country $=0.823$; eigenvalue $=1.939 ;$ variance explained $=64.65 \%$.

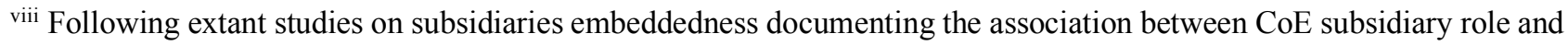
subsidiary embeddedness (Andersson, et al., 2002; Holm and Pedersen, 2000), we included CoE in Model 1. However, we also re-ran the analysis and included the variable in the estimations after including the quadratic term. The results were stable.

ix Perri et al. (2013) suggested an inverted U-shaped relationship between quality vertical linkages (which is a broader concept of business embeddedness) and perceived product-market competition. Given the focus of our study, which is on the relationship between business embeddedness and regulatory competitive constraints in service-supplying sectors, and the size of our sample, we only controlled for the linear effect of product-market competition and avoided inserting the related squared term to rule out multicollinearity problems. 


\section{REFERENCES}

Aaker, J. C. Mbiti, I. M. 2010. Mobile Phones and Economic Development in Africa. Journal of Economic Perspectives, 24, 207-232.

Aiken, L. S. West, S. G. 1991. Multiple Regression: Testing and interpreting interactions. Sage. Newbury Park, CA.

Ambos, B., Asakawa, K., Ambos, T. C. 2011. A dynamic perspective on subsidiary autonomy. Global Strategy Journal, 1, 301-316.

Andersson, U., Björkman, I., Forsgren, M. 2005. Explaining subsidiary network embeddedness: The impact of headquarters control mechanisms. International Business Review, 14, 521-538.

Andersson, U., Dellestrand, H., Pedersen, T. 2014. The contribution of local environments to competence creation in multinational enterprises. Long Range Planning, 47, 87-99.

Andersson, U. Forsgren, M. 1996. Subsidiary embeddedness and control in the multinational corporation. International Business Review, 5, 487-508.

Andersson, U. Forsgren, M. 2000. In search of centre of excellence: Network embeddedness and subsidiary roles in multinational corporations. Management International Review, 40, 329-350.

Andersson, U., Forsgren, M., Holm, U. 2001. Subsidiary embeddedness, expected performance and competence development in MNCs - A multilevel analysis. Organization Studies, 22, 1013-1034.

Andersson, U., Forsgren, M., Holm, U. 2002. The strategic impact of external networks: Subsidiary performance and competence development in the multinational corporation. Strategic Management Journal, 23, 979-996.

Andersson, U., Forsgren, M., Holm, U. 2007. Balancing subsidiary influence in the federative MNC: a business network view. Journal of International Business Studies, 38, 802-818.

Andersson, U., Johanson, J., Vahlne, J.-E. 1997. Organic acquisitions in the internationalization process of the business firm. Management International Review, 37, 67-84.

Baptista, R. Swann, P. 1998. Do firms in clusters innovate more? Research Policy, 27, 525-540.

Barney, J. B. 1986. Strategic factor markets: expectations, luck, and business strategy. Management Science, $32,1231-1241$.

Barone, G. Cingano, F. 2011. Service Regulation and Growth: Evidence from OECD Countries*. The Economic Journal, 121, 931-957.

Bartlett, C. A. Ghoshal, S. 1989. Managing Across Borders: The transnational solution. Harvard Business School Press. Boston.

Belsley, D., Kuh, E., Welsch, R. 1980. Regression Diagnositics. Wiley. New York.

Bourlès, R., Cette, G., Lopez, J., Mairesse, J., Nicoletti, G. 2010. Do product market regulations in upstream sectors curb productivty growth? Panel data evidence for OECD countries, NBER Working Paper series, 16520 .

Campbell, D. T. Fiske, D. W. 1959. Convergent and discriminant validation by the multitrait-multimethod matrix. Psychological Bulletin, 56, 81-105.

Campbell, J. P. 1982. Editorial: Some remarks from the matrix. Journal of Applied Psychology, 67, 691-7000.

Chi, T. 1994. Trading in strategic resources: Necessary conditions, transaction cost problems, and choice of exchange structure. Strategic Management Journal, 15, 271-290.

Clifton, J., Comín, F., Díaz-Fuentes, D. 2011. From National Monopoly to Multinational Corporation: How Regulation Shaped the Road towards Telecommunications Internationalization. Business History, 53, $761-781$.

Cohen, J., Cohen, P., West, S. G., Aiken, L. S. 2003. Applied Multiple Regression/Correlation Analysis for the Behavioral Sciences. 3rd ed ed. Lawrence Erlbaum. Mahwah, NJ.

Conway, P., De Rosa, D., Nicoletti, G., Steiner, F. 2006. Regulation, Copeition and productivity convergence, OECD Economics Department Working Papers N. 509. OECD Publishing.

Conway, P. Nicoletti, G. 2006. Product Market Regulation in the Non-Manufacturing Sectors of OECD Countries: Measurement and Highlights, OECD Economics Department Working Paper.

Cortina, J. 1993. Interaction, nonlinearity, and multicollinearity:Implications for multiple regression. Journal of Management, 19, 915-922.

Cronbach, L. J. Meehl, P. E. 1955. Construct validity in psychological tests. Psychological Bulletin, 52, 281302. 
Cuervo-Cazurra, A., Andersson, U., Brannen, M. Y., Nielsen, B., Reuber, A. R. 2016. Can I Trust Your Findings? Ruling out Alternative Explanations in International Business Research. Journal of International Business Studies, 47, 881-897.

Dell. 2015. https://www.dell.com/learn/us/en/uscorp1/press-releases/2015-09-14-dell-announces-its-new-inchina. Accessed on August 30, 2018.

Dierickx, I. Cool, K. 1989. Asset stock accumulation and sustainability of competitive advantage. Management Science, 35, 1504-1511.

Dike, M. C. 2018. Cross-border Expansion and Competitive Interactions of Mobile Network Operators in SubSaharan Africa. Doctoral DIssertation 92/2018. Aalto.

Dyer, J. H. Nobeoka, K. 2000. Creating and managing a high-performance knowledge-sharing network: the Toyota case. Strategic Management Journal, 21, 345-368.

Dyer, J. H. Singh, H. 1998. The relational view: Co-operative strategy and source of interorganisational competitive advantage. Academy of Management Review, 23, 660-679.

Egelhoff, W. G. 1988. Organizing the Multinational Enterprise: An Information-Processing Perspective. Cambridge, MA. Ballinger.

Erramilli, M. K. Rao, C. P. 1990. Choice of foreign market entry modes by service firms: role of market knowledge. Management International Review, 30, 135-150.

Figueiredo, P. N. 2011. The role of dual embeddedness in the innovative performance of MNE subsidiaries: evidence from Brazil. Journal of management studies, 48, 417-440.

Ford, D., (Ed.). 1990. Understanding Business Markets: Interaction, Relationships and Networks Academia Press, London.

Forsgren, M. 1989. Managing the Internationalization Process. The Swedish Case. Routledge. London.

Forsgren, M., Holm, U., Johanson, J. 2005. Managing the embedded multinational - A business network view. Edward Elgar. Cheltenham.

Forsgren, M. Johanson, J., (Eds.). 1992. Managing Networks in International Business. Gordon and Breach, Philadelphia.

François, J. Hoekman, B. 2010. Services trade and policy. Journal of Economic Literature, 48, 642-692.

Frost, T. S., Birkinshaw, J. M., Ensign, P. C. 2002. Centers of excellence in multinational corporations. Strategic Management Journal, 23, 997-1018.

Gates, S. R. Egelhoff, W. G. 1986. Centralization in headquarters-subsidiary relationships. Journal of International Business Studies, 17, 71-92.

Golden, T. D. Veiga, J. F. 2005. The Impact of Extent of Telecommuting on Job Satisfaction: Resolving Inconsistent Findings. Journal of Management, 31, 301-318.

Granovetter, M. 1985. Economic action and social structure: The problem of embeddedness. American Journal of Sociology, 91, 481-510.

Granovetter, M. 1992. Economic institutions as social constructions: a framework for analysis. Acta Sociologica, 35, 3-11.

Gupta, A. K. Govindarajan, V. 1991. Knowledge flows and the structure of control within multinational corporations. Academy of Management Review, 16, 768-792.

Hagedoorn, J. 2006. Understanding the cross-level embeddedness of interfirm partnership formation. Academy of Management Review, 31, 670-680.

Hair, J. F., Black, W. C., Babin, B. J., Anderson, R. E., Tatham, R. L. 2006. Multivariate Data Analysis. Pearson Education. Upper Saddle River, NJ.

Håkanson, L. Nobel, R. 2001. Organization characteristics and reverse technology transfer. Management International Review, 41, 392-420.

Håkansson, H., (Ed.). 1982. International Marketing and Purchasing of Industrial Goods: An Interaction Approach, John Wiley \& Sons. Chichester.

Håkansson, H. Johanson, J. 1988. Formal and informal cooperation strategies in international industrial networks.In Contractor, F. P. Lorange, (Eds.), Cooperative Strategies in International Business. Lexington Books, Massachusetts.

Hallin, C. Holmström Lind, C. 2011. Revisiting the external impact of MNCs: An empirical study of the mechanisms behind knowledge spillovers from MNC subsidiaries. International Business Review, In Press, Corrected Proof, Available online 18 February 2011.

Hedlund, G. 1980. The role of foreign subsidiaries in strategic decision-making in Swedish multinational corporations. Strategic Management Journal, 1, 23-36. 
Hite, J. M. 2003. Patterns of multidimensionality among embedded network ties: A typology of relational embeddedness in emerging entrepreneurial firms. Strategic Organization, 1, 9-49.

Holm, U., Holmström, C., Sharma, D. 2005. Competence development through business relationships or competitive environment? Subsidiary impact on MNC competitive advantage. Management International Review, 45, 197-218.

Holm, U. Pedersen, T. 2000. The emergence and impact of MNC centres of excellence: A subsidiary perspective. Palgrave MacMillan.

Holmes, R. M., Miller, T., Hitt, M. A., Salmador, M. P. 2013. The interrelationships among informal institutions, formal institutions, and inward foreign direct investment. Journal of Management, 39, 531-566.

Johanson, J. Vahlne, J.-E. 2009. The Uppsala internationalization process model revisited: From liability of foreignness to liability of outsidership. Journal of International Business Studies, 40, 1411-1431.

Jones, G. R. Hill, C. W. 1988. Transaction cost analysis of strategy-structure choice. Strategic Management Journal, 9, 159-172.

Joskow, P. L. 2002. Transaction cost economics, antitrust rules, and remedies. Journal of Law, Economics, and Organization, 18, 95-116.

Klein, B., Crawford, R. G., Alchian, A. A. 1978. Vertical integration, appropriable rents, and the competitive contracting process. Journal of Law, Economics, and Organization, 21, 297.

Kongsrud, P. M. Wanner, I. 2005. The Impact of Structural Policies on Trade-Related Adjustment and the Shift to Services, OECD Economics Department Working paper.

Levine, R. Renelt, D. 1992. A sensitivity analysis of cross-country growth regressions. American Economic Review, 82, 942-963.

Li, G., (Ed.). 1985. Robust regression. In Exploring Data Tables, Trends, and Shapes. Wiley, New York.

Martinez, J. I. Jarillo, J. C. 1989. The Evolution of Research on Coordination Mechanisms in Multinational Corporations. Journal of International Business Studies, 20, 489-514.

McEvily, B. Marcus, A. 2005. Embedded ties and the acquisition of competitive capabilities. Strategic Management Journal, 26, 1033-1055.

McEvily, B., Perrone, V., Zaheer, A. 2003. Trust as an organizing principle. Organization Science, 14, 91-103.

Melvin, J. R. 1989. Trade in producer services: a Heckscher-Ohlin approach. The Journal of Political Economy, 97, 1180-1196.

Meyer, K. E. 2009. Motivating, testing, and publishing curvilinear effects in management research. Asia Pacific Journal of Management, 26, 187-193.

Meyer, K. E., Mudambi, R., Narula, R. 2011. Multinational Enterprises and Local Contexts: The Opportunities and Challenges of Multiple Embeddedness. Journal of Management Studies, 48, 235-252.

Mudambi, R. Navarra, P. 2004. Is knowledge power? Knowledge flows, subsidiary power and rent-seeking within MNCs. Journal of International Business Studies, 35, 385-406.

Mustilli, F. Pelkmans, J. 2012. Securing EU Growth from Services, Centre for European Policy Studies (CEPS), Brussels.

Nicoletti, G. 2001. Regulation in services: OECD patterns and economic implications, OECD Economics Department Working Papers, No. 287. OECD Publishing.

North, D. C. 1990. Institutions, Institutional Change and Economic Development. Cambridge University Press. Cambridge.

OECD. 1992. Technology and The Economy. OECD. Paris.

OECD. 2001. Product Market Regulation Database www.oecd.org/economy/pmr.

OECD-EUROSTAT. 2006. High-technology manufacturing and knowledge-intensive services sectors. EUROSTAT, Luxembourg.

Peng, M. W., Sunny, L., Brian, P., Hao, C. 2009. The Institution-based view as a third leg for a strategy tripod. Academy of Management Perspective, 23, 63-81.

Penrose, E. 1959. The Theory of the Growth of the Firm. Basil Blackwell. Oxford, England.

Perri, A., Andersson, U., Nell, P., Santangelo, G. D. 2013. Balancing the trade-off between learning prospects and spillover risks: MNC subsidiaries' vertical linkages patterns in developed countries Journal of World Business, 48, 503-514.

Peteraf, M. A. 1993. The cornerstones of competitive advantage: A resource-based view. Strategic Management Journal, 14, 179-191.

Podsakoff, P., MacKenzie, S. B., Lee, J. Y. 2003. Common method biases in behavioral research: A critical review of the literature and recommended remedies. Journal of Applied Psychology 88, 879-903. 
Podsakoff, P. M. Organ, D. W. 1986. Self-reports in organizational research: Problems and prospects. Journal of Management 12, 531-544.

Porter, M. E. 1990. The Competitive Advantage of the Nations. Free Press. New York.

Rabbiosi, L. Santangelo, G. D. 2012. Parent company's benefits from reverse knowledge transfer: The role of the liability of newness in MNEs. Journal of World Business, 48, 160-170.

Rabbiosi, L. Santangelo, G. D. 2018. Host country corruption and the organization of HQ-subsidiary relationships. Journal of Internaitonal Business Studies, https://doi.org/10.1057/s41267-018-0169-1.

Rowley, T., Behrens, D., Krackhardt, D. 2000. Redundant governance structures: An analysis of structural and relational embeddedness in the steel and semiconductor industries. Strategic Management Journal, 21, 369-386.

Rumelt, R. 1984. Towards a strategie theory of the firm.In Lamb, R., (Ed.), Competitive Strategie Management. Prentiee-Hall, Englewood Cliffs NJ.

Santangelo, G. D. 2012. The tension of information sharing: Effects on subsidiary embeddedness. International Business Review, 21, 180-195.

Santangelo, G. D. Meyer, K. 2011. Extending the internationalization process model: Increases and decreases of MNE commitment in emerging economies. Journal of International Business Studies, 42, 894-909.

Santangelo, G. D., Meyer, K. E., Jindra, B. 2016. MNE Subsidiaries' Outsourcing and InSourcing of R\&D: The Role of Local Institutions. Global Strategy Journal, 6, 247-268.

Scherer, F. M. 1984. Using linked patent and R\&D data to measure inter-industry technology flows.In Griliches, Z., (Ed.), R\&D, Patents and Productivity. University of Chicago Press, Chicago.

Siemsen, E., Roth, A., Oliveira, P. 2010. Common Method Bias in Regression Models With Linear, Quadratic, and Interaction Effects. Organizational Research Methods, 13, 456-476.

Smither, J. W., Collins, H., Buda, R. 1989. When ratee satisfaction influences performance evaluations: A case of illusory correlation. Journal of Applied Psychology, 74, 599-605.

Snell, S. 1992. Control theory in strategic human resource management: The mediating effect of administrative information. Academy of Management Journal, 35, 292-327.

Stopford, J. M. Wells, L. T. 1972. Managing the Multinational Enterprise: Organization of the Firm and Ownership of the Subsidiaries. London. Longman.

Teece, D. J. 1986. Profiting from technological innovation: Implications for integration, collaboration, licensing and public policy. Research Policy 15, 285-305.

Uzzi, B. 1997. Social structure and competition in interfirm networks. The paradox of embeddedness. Administrative Science Quarterly, 42, 35-67.

Von Hippel, E. 1998. The Sources of Innovation. Oxford University Press. New York.

Wernerfelt, B. 1984. A resource based view of the firm. Strategic Management Journal, 5, 171-180.

Williams, R. 2000. A note on robust variance estimation for cluster-correlated data. Biometrics, 56, 645-646.

Williamson, O. E. 1975. Markets and Hierarchies, Analysis and Antitrust Implications: A study in the economics of internal organization. Free Press. New York.

Williamson, O. E. 1985. The Economic Institutions of Capitalism. The Free Press. New York.

Wong, X., Yen, D. C., Fang, X. 2004. E-commerce development in China and its implication for business. Asia Pacific Journal of Marketing and Logistics, 16, 68-83.

Xie, J. L. Johns, G. 1995. Job Scope and Stress: Can Job Scope Be Too High? Academy of Management Journal, 38, 1288-1309.

Zajac, E. J. Olsen, C. P. 1993. From transaction cost to transactional value anlasyis: Implications for the study of interorganizational srategies. Journal of Management Studies, 30, 131-145. 


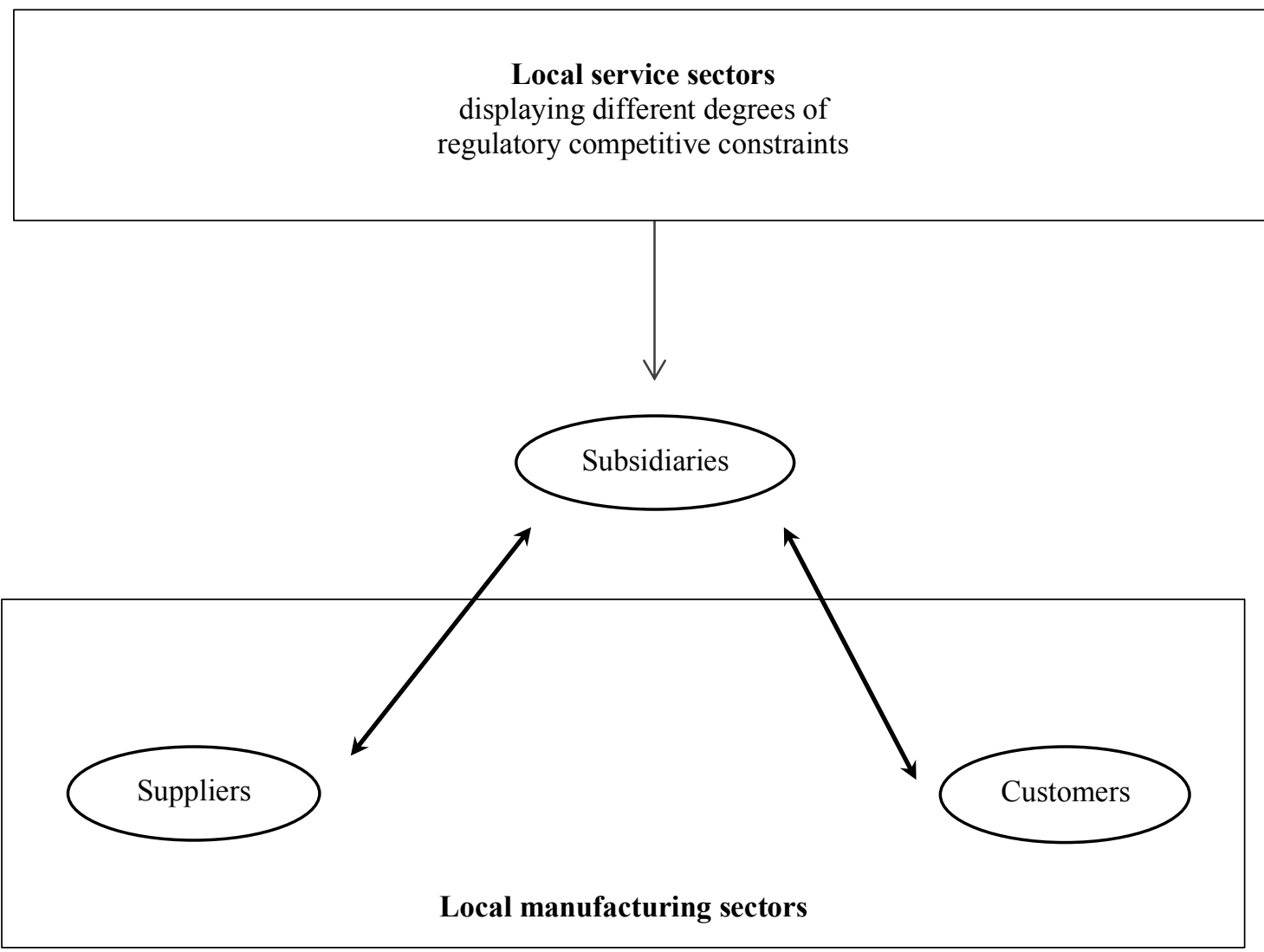

Figure 1. Influence of regulatory competitive constraints in local service sectors on subsidiaries embeddedness with local manufacturing partners 
Regulatory competitive constraints in local service sectors

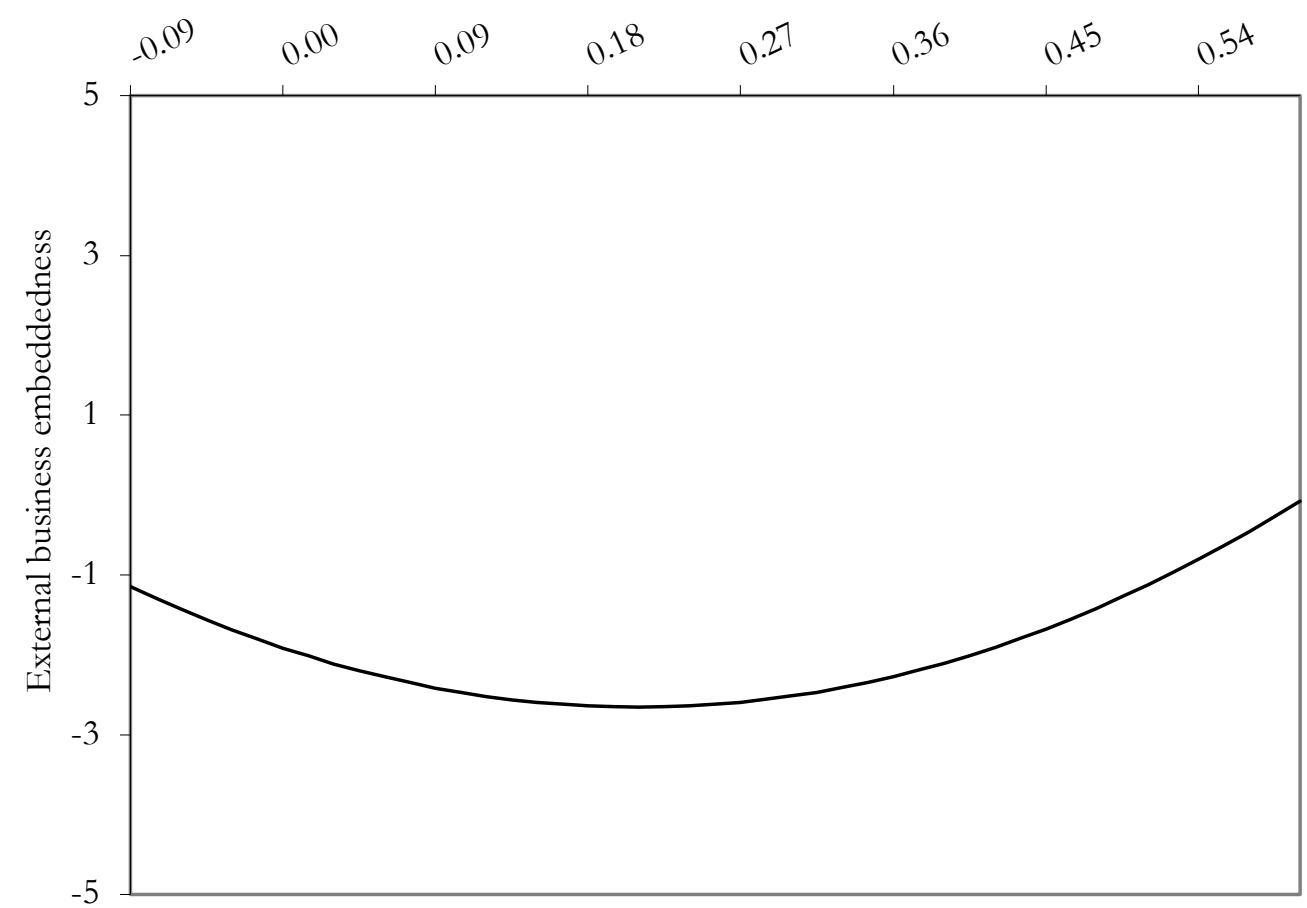

Figure 2. Relationship between regulatory competitive constraints in local service sectors and subsidiary external business embeddedness with local partners

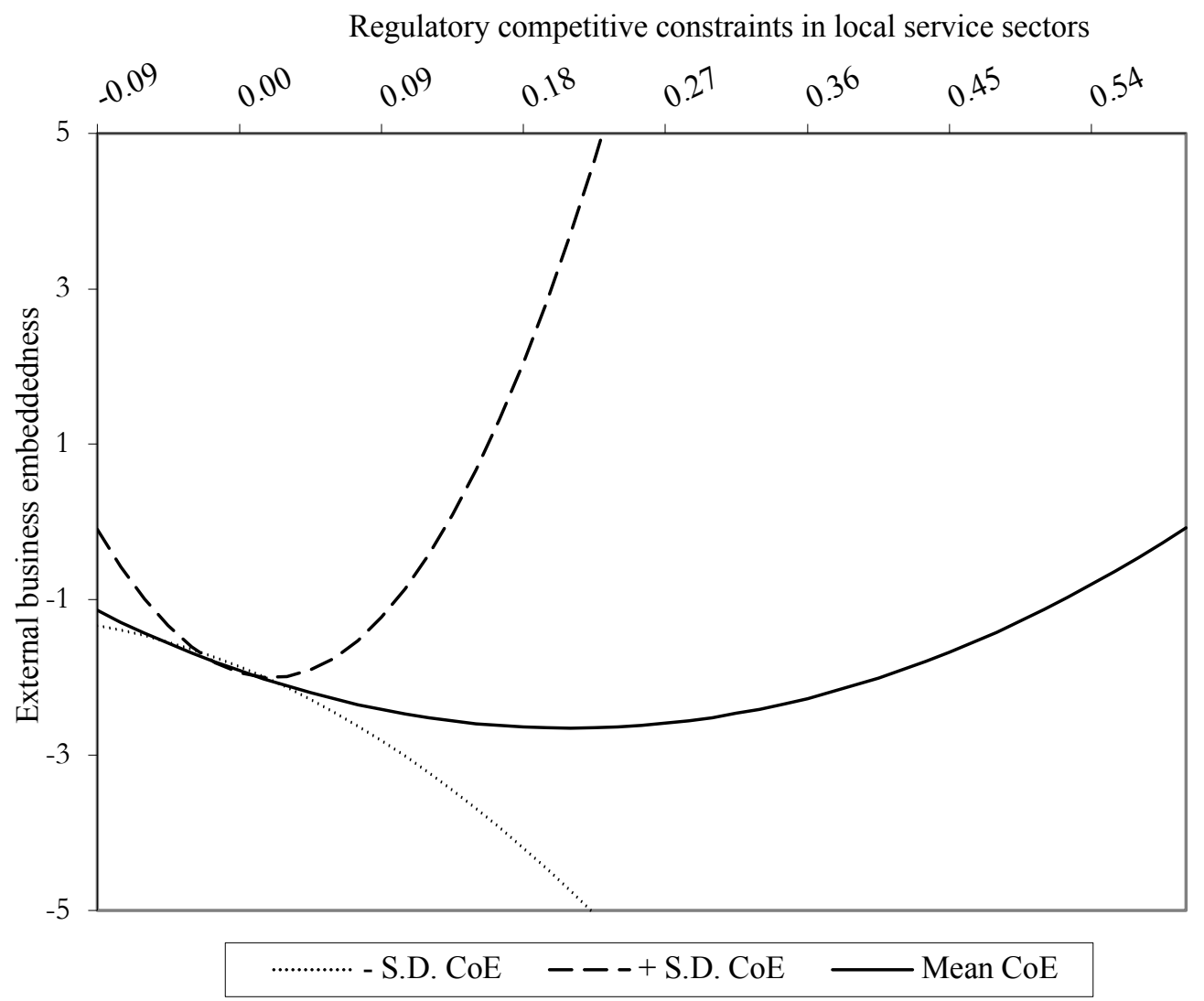

Figure 3. Moderating effect of center-of-excellence subsidiary role 


\begin{tabular}{|c|c|c|c|c|c|c|c|c|c|c|c|c|c|}
\hline & & 1 & 2 & 3 & 4 & 5 & 6 & 7 & 8 & 9 & 10 & 11 & 12 \\
\hline 1 & External business embeddedness & 1 & & & & & & & & & & & \\
\hline 2 & Product-market competition & $0.559 * *$ & 1 & & & & & & & & & & \\
\hline 3 & Degree of formalization & 0.059 & -0.075 & 1 & & & & & & & & & \\
\hline 4 & Perceived control by headquarters & 0.091 & 0.104 & 0.042 & 1 & & & & & & & & \\
\hline 5 & Expatriates & 0.066 & -0.028 & 0.118 & $0.262 * *$ & 1 & & & & & & & \\
\hline 6 & Acquisition & -0.015 & 0.132 & -0.019 & 0.007 & -0.117 & 1 & & & & & & \\
\hline 7 & Subsidiary age & 0.207 & 0.210 & -0.179 & 0.051 & -0.041 & -0.054 & 1 & & & & & \\
\hline 8 & Subsidiary size & $0.299 * *$ & $0.239 *$ & -0.099 & 0.039 & -0.190 & 0.142 & $0.237 * *$ & 1 & & & & \\
\hline 9 & High-tech & $0.228 * *$ & 0.092 & $0.275^{* *}$ & 0.101 & 0.109 & $0.2163^{* *}$ & 0.021 & -0.162 & 1 & & & \\
\hline 10 & $\begin{array}{l}\text { Regulatory competitive constraints } \\
\text { in service-supplying sectors }\end{array}$ & $-0.238 * *$ & -0.146 & 0.158 & -0.134 & $0.293 * *$ & -0.147 & -0.003 & $-0.256^{* *}$ & -0.019 & 1 & & \\
\hline 11 & $\mathrm{CoE}$ & 0.204 & 0.174 & 0.001 & -0.197 & -0.182 & 0.019 & 0.112 & $0.354 * *$ & -0.158 & -0.206 & 1 & \\
\hline 12 & Performance & $0.319 * *$ & 0.193 & -0.092 & -0.021 & 0.104 & -0.059 & 0.006 & $0.310 * *$ & $-0.288 * *$ & $-0.237 * *$ & 0.182 & 1 \\
\hline \multicolumn{2}{|c|}{ Min. } & -2.833 & 1 & -1.884 & -2.763 & 0 & 0 & 1 & 0.010 & 0 & -0.063 & -1.424 & -2.330 \\
\hline \multicolumn{2}{|c|}{ Max. } & 2.128 & 5 & 1.994 & 0.964 & 1 & 1 & 120 & 0.780 & 1 & 0.545 & 2.240 & 1.899 \\
\hline \multicolumn{2}{|c|}{ Mean } & -0.085 & 2.916 & -0.083 & -0.052 & 0.190 & 0.226 & 36.905 & 0.133 & 0.167 & 0.001 & 0.012 & 0.029 \\
\hline \multicolumn{2}{|c|}{ Std. Dev. } & 0.990 & 0.979 & 0.972 & 1.012 & 0.395 & 0.421 & 30.267 & 0.129 & 0.375 & 0.089 & 1.005 & 1.005 \\
\hline
\end{tabular}

** Significant at the $5 \%$ level (two-tailed). $\mathrm{N}=84$. 
Table II Hierarchical regression analysis

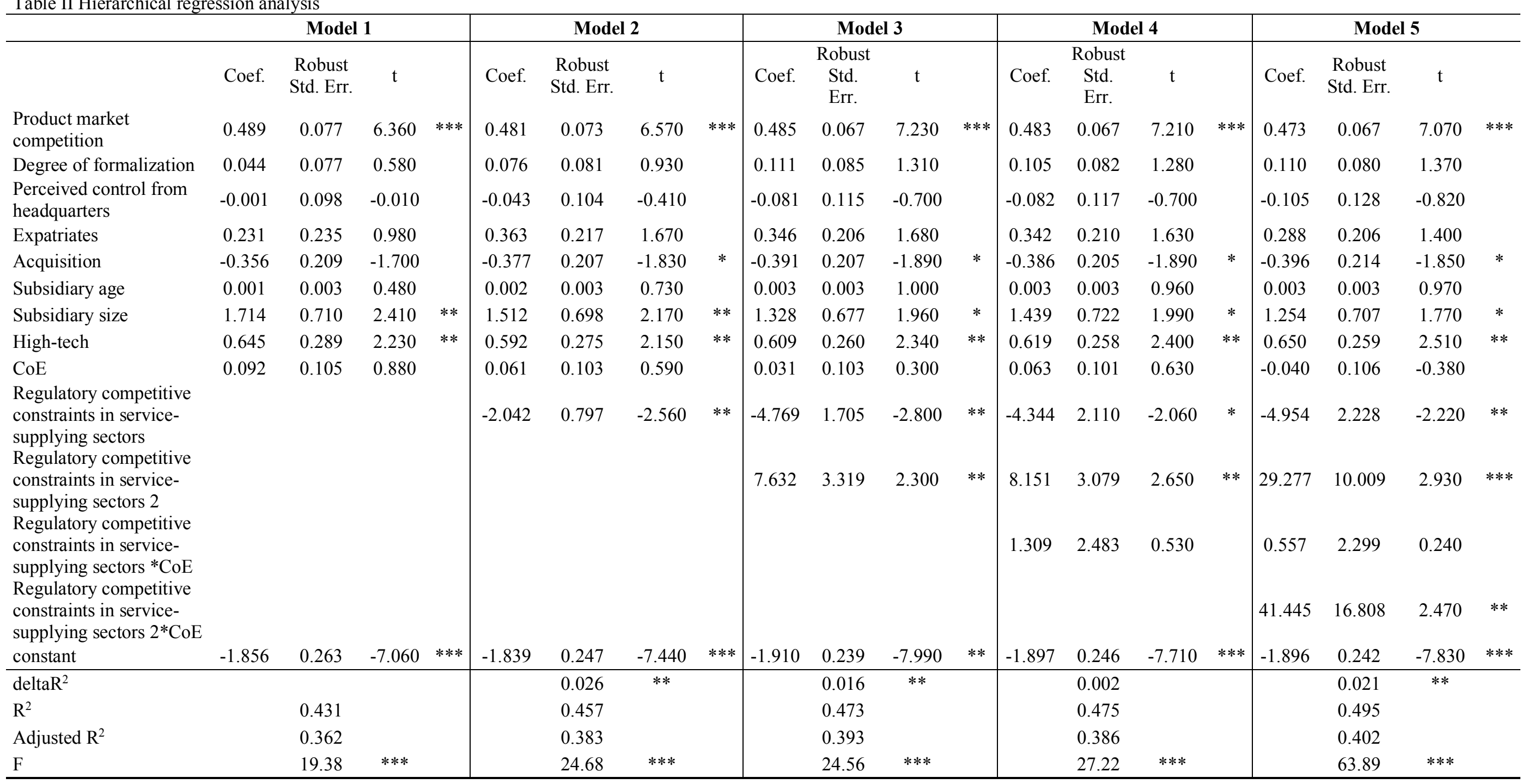

*** significant at the $1 \%$ level $* *$ significant at the $5 \%$ level $* * *$ significant at the $10 \%$ level. No. obs. 84 . 